\title{
APPLICATION OF ALUMINIUM HYBRID COMPOSITES IN AUTOMOTIVE INDUSTRY
}

\author{
Blaža Stojanović, Lozica Ivanović
}

Subject review

Strict requirements that are put on mechanical constructions from the aspect of increase of exploitation periods and reduction of their weights, therefore of their prices as well, implicate developments and applications of new composite materials with matrices of lightweight metals. Composite materials with metal matrices are used for engine cylinders, pistons, disc and drum brakes, Cardan shafts and for other elements in automotive and aviation industry. The most important type of metallic materials is composite materials with matrices of aluminium alloys due to a set of their beneficial properties. Improvement of mechanical, especially tribological properties of hybrid composites were provided by the use of certain reinforce materials such as $\mathrm{SiC}_{2} \mathrm{Al}_{2} \mathrm{O}_{3}$ and graphite in defined weight or volumetric share. New developed hybrid composites with aluminium matrices have significantly higher resistance to wear, higher specific stiffness and higher resistance to fatigue. By the increase of quantities of produced elements made of hybrid composites, decrease of their prices is induced that even further enlarge their applications. The applications of aluminium hybrid composites are considered from the aspect and with the focus on automotive industry.

Keywords: aluminium; application; automotive industry; composites; $M M C$

Primjena aluminijskih hibridnih kompozita u automobilskoj industriji

Pregledni članak

Pooštravanje konstrukcijskih zahtjeva s aspekta povećanja radnog vijeka i smanjenja mase, a samim tim i cijene konstrukcije, iniciralo je razvoj i primjenu novih materijala s osnovom od lakih metala. Kompoziti s metalnom matricom nalaze sve veću primjenu pri izradi košuljica cilindara motora, klipova, kočionih diskova i doboša, kardanskih vratila kao i drugih dijelova u automobilskoj i avio industriji. Posebno mjesto, od svih metalnih materijala, zauzimaju kompoziti na osnovi legure aluminija zbog niza dobrih svojstava. Poboljšanje mehaničkih, a posebice triboloških karakteristika hibridnih kompozita moguće je uporabom određenih ojačivača, najčešće $\mathrm{SiC}, \mathrm{Al}_{2} \mathrm{O}_{3}$ i grafita, u odgovarajućem masenom ili volumenskom udjelu. Novodobiveni hibridni kompoziti s aluminijskom osnovom imaju znatno povećanu otpornost na habanje, povećanu specifičnu krutost i povećanu otpornost na zamor. Povećanjem količine proizvedenih dijelova od aluminijskih kompozitnih materijala dolazi do smanjenja cijene ovih dijelova, što dodatno povećava područje njihove primjene. U radu su prikazani primjeri primjene aluminijskih hibridnih kompozita s osvrtom i težištem na automobilskoj industriji.

Ključne riječi: aluminij; automobilska industrija; kompoziti; $M M C$; primjena

\section{Introduction}

Composites, as relatively new materials, still do not have a generally accepted definition. Composites are made by compounding of two or more different materials. Their basic constituents have own different characteristics and properties, while the compound presents a completely new material. This material has its own unique, completely new and different properties in relation to constituent components. The aim of this material compounding is to improve structural, tribological, thermal, chemical or some other material properties. Constituent components do not mix and dissolve between each other, so two or more phases are present within composite material $[1,2,3]$.

In general, composite materials are made of matrix, constituent with the largest quantity share in relation to other components and reinforce materials that are used in order to obtain projected properties. In case of metal matrices composites, aluminium and its alloys are widely used. Aluminium and its alloys provide the use of different reinforce and improve materials. The basic advantages of composite materials with aluminium matrices in relation to materials without reinforce materials are:

- Higher strength

- $\quad$ Higher stiffness

- $\quad$ Reduced density(weight)

- Improved properties at high temperatures

- Controlled thermal expansion coefficient

- $\quad$ Controlled heating of material

- Improved and adoptive electrical conductivity
- Improved resistance to abrasion and wear

- Controlled weight (especially for applications with piston like motions)

- Improved amortization ability.

But aluminium alloys have certain defects such as high thermal expansion coefficient and inadequate tribological characteristics. Higher stiffness and strength, resistance to fatigue, as well as improvement of tribological characteristics, are obtained by additions of proper reinforce and improve materials and by that, modelling of certain aluminium composites. As reinforce materials, $\mathrm{SiC}, \mathrm{Al}_{2} \mathrm{O}_{3}$ and graphite are usually used [4].

Influences of $\mathrm{SiC}$, and graphite on tribological and mechanical properties are different. By increases of weight or volumetric shares of $\mathrm{SiC}$ and $\mathrm{Al}_{2} \mathrm{O}_{3}$, improvement of mechanical properties is obtained, while the increase of weight or volumetric share of graphite improves tribological properties of considered composite materials. Optimal tribological and mechanical properties are obtained through combination of proper shares of those two constitutive materials.

Decreases of prices of elements made of aluminium composite materials obtained by increases of their quantities in production additionally enlarge area of their usages.

The researches at global market show that 4,1 millions of kilograms of MMC were used in 2007, while in 2008. 4,4 millions of kilograms of MMC were used. The projection for 2013 is that 5,9 millions of kilograms of MMC will be needed. The largest share of application belongs to ground transport that is 2,4 millions of 
kilograms of MMC in 2008 (Fig. 1). The projection for this share in 2013 is that 3,2 millions of kilograms of MMC will be needed with annual increase of 5,5\%.

The significant area of MMC application is electrical industry. The usage of MMC rises from 1,3million of kilograms in 2007 to 1,4 million of kilograms in 2008. Prediction is that 2,1 millions of kilograms will be used in 2013 , with annual increase of $6,5 \%$ [5].

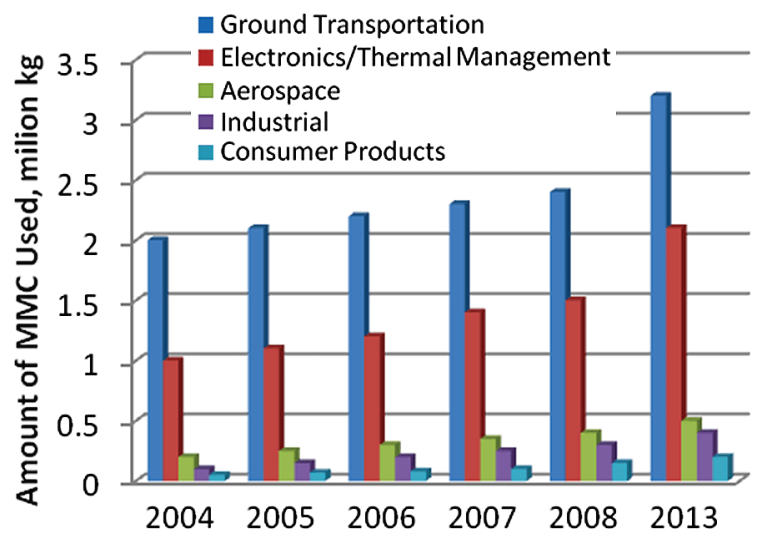

Figure 1 Increasing trend of MMC production worldwide with typical applications [5]

Projections of market needs and profits related to production quantities of MMC for period of time from 2012 to 2019, based on latest analyses of global world market, are shown in Fig. 2 [6]. Continual increase of real annual market needs for MMC from 5000 to 8000 tonnes is obvious.

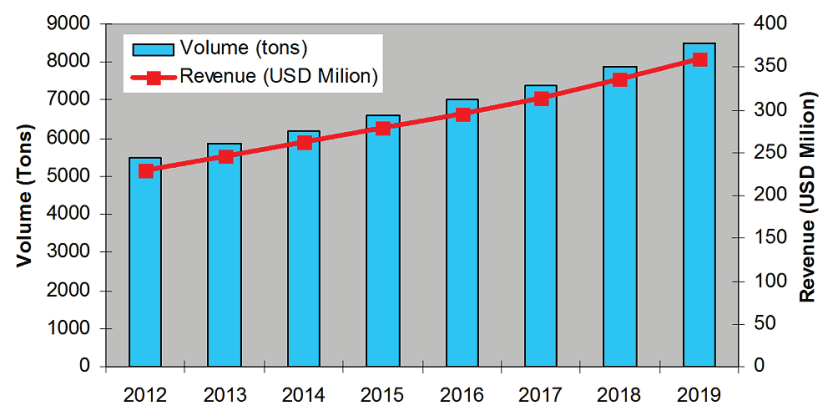

Figure 2 Projections of market needs and related profits of MMC production for period 2012 - 2019 [6]

\section{Applications of MMC at cars}

From the aspect that over $50 \%$ of global production of composite material with metal matrices is used at automotive industry, the focus of application of this material will be put on cars. Large numbers of car parts are made of composite materials. The ratios of their prices and qualities present main causes for applications of those materials. It is obvious that composite materials with metal matrices are generally used for responsible parts at modern cars $[7 \div 18]$.

\subsection{Engine pistons}

Engine pistons operate in very hard dynamical, thermal and mechanical conditions. The pistons are loaded to cyclic mechanical load with frequency of around $100 \mathrm{~Hz}$, so fatigue damages are primarily important. Pistons must provide intimate contacts with cylinders at maximal pressures during expansion periods. Dynamic endurance, high resistance to wear and thermal expansion coefficient are necessary characteristics of materials for cylinders. It is also necessary that pistons can operate at temperatures of around $3000{ }^{\circ} \mathrm{C}$. Due to temperature gradients and thermal cycles, high thermal conductivity must be provided in order to reduce temperatures and thermal impacts.

Breakthrough in the area of aluminium MMC application is done by production of pistons for diesel engines at Toyota car manufacturer [3, 7, 19]. The serial production of those pistons started in Japan at 1983. The materials for the pistons were composite materials with aluminium alloy matrices reinforced by ceramic particles and fibres in order to reduce wear and to improve resistance to material fatigue at high temperatures. Those composites were made by squeeze casting method. Due to large series in production of over 100000 items per mount, the produced parts had excellent quality at satisfactory prices.

Metal matrices composites with ceramic reinforcements used for production of pistons have significantly higher resistance to wear in relation to materials used for matrices. Simultaneously, pistons have small values of thermal expansion coefficients that provide use of narrow tolerances, so that it results in increasing of maximal allowed pressures and improved thermal conductivity properties [7]. Lower weights of pistons also have positive influence to beneficial properties of materials in exploitation. Besides that, method of MMC casting is quite simpler than traditional method of piston fabrication. In general, beside higher prices of aluminium materials by units, summary prices of pistons are smaller than pistons made of traditional materials. Large numbers of positive performances of MMC application implicate use of those materials for pistons made. As reinforce materials to metal matrices silicon carbide ( $\mathrm{SiC}$ ) is usually used especially at race cars. The pistons made of MMC are widely used in Asia and West Europe car producers (Fig. 3).
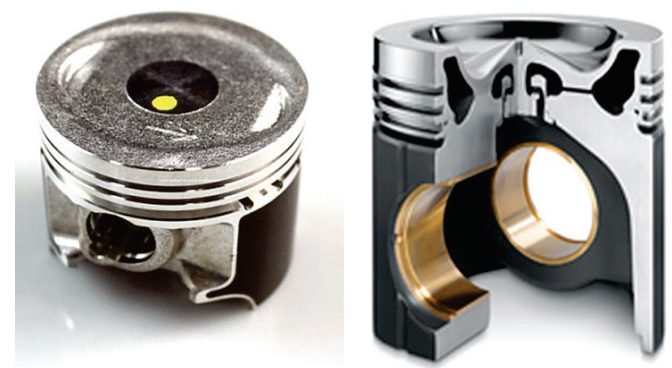

Figure 3 Pistons made of aluminium MMC

\subsection{Engine cylinders}

Wide usage of aluminium alloys for production of engine block is main cause of application of those materials for cylinders. Serial production of cylinder barrel made of aluminium MMC started in 1990. It was used for the first time at 2,3 litre engine of Honda Prelude [7]. Hybrid composite material with aluminium matrix was reinforced by carbon and $\mathrm{Al}_{2} \mathrm{O}_{3}\left(12 \% \mathrm{Al}_{2} \mathrm{O}_{3}+9 \%\right.$ 
carbon) for this application. The cylinders barrels were made by squeeze castings at medium pressure. The example of engine with cylinder barrel made of aluminium MMC is presented in Fig. 4.

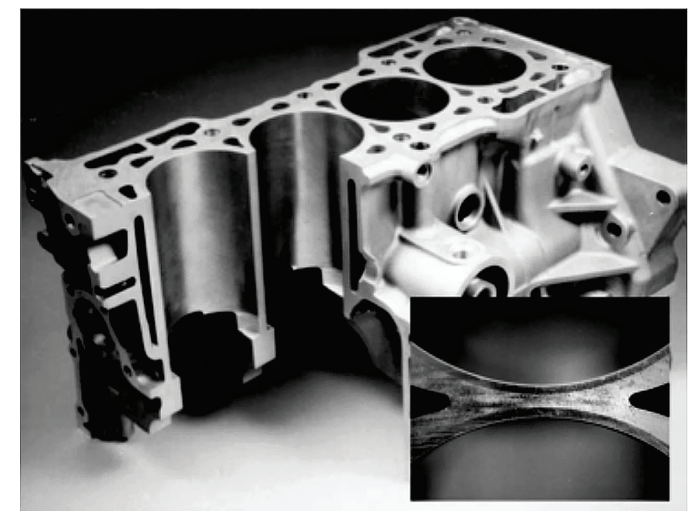

Figure 4 Engine of Honda Prelude with cylinder barrel made of aluminium MMC

Resistance to wear of aluminium MMC is higher than resistance to wear of cast iron. The summary weight of engine block is reduced by $20 \%$ by application of MMC. Besides that, aluminium MMC has higher thermal conductivity and, by that, operating temperature is lower so exploitation period is longer. Thickness of cylinder barrel is smaller than one made of cast iron, so the increase of working volume of exact engine is provided without its redesign.

The engines with cylinder barrel made of MMC composite are used at Honda S2000 - sport cars, also at Acura NSX cars type and at Porsche Bower motors [3, 7]. The engines at Toyota Celica 2000 cars also have cylinder barrels made of MMC. The cylinder barrels made of aluminium MMC are used, also, at high performances Honda motorbikes. Those materials are produced by powder metallurgy methods.
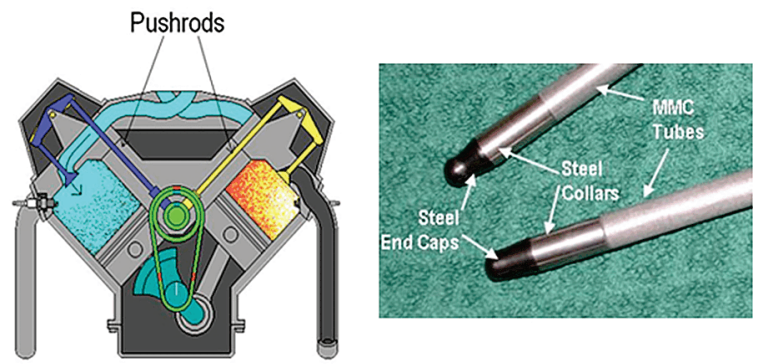

Figure 5 Pushrods made of aluminium MMC at engines

\subsection{Engine pushrods}

Aluminium MMC reinforced by fibres is used for production of pushrods of valves at engines. As reinforcing material, fibres of $\mathrm{Al}_{2} \mathrm{O}_{3}$ are used, while for the matrix aluminium alloys are used. The first producer of these parts made of MMC is 3M Corporation (Fig. 5). The pushrods of engine valve made of alumina MMC have $25 \%$ higher stiffness to flexion and twice higher absorption capacity than the related parts made of common steel. Due to smaller density and weight, number of rotations can be increased for $200 \div 4001 / \mathrm{min}$ without additional dynamic loads. The exploitation period of those pushrods are significantly higher than ones made of steels $[14,16]$.

\subsection{Engine connection rod}

By making engine connection rod of aluminium MMC mass reduction of $57 \%$ related to steel one is obtained. By reduction of piston/connection rod mass, vibrations during operation are also reduced. By that, reduction of load at crankshaft and at its bearing is also done, energy losses due to friction are also reduced, the same as engine fuel consumption [14]. It is concluded that reduction of crankshaft by $1 \mathrm{~kg}$ caused related reduction of balancing counterweight by $7 \mathrm{~kg}$ [14]. As material for making of connection rod, composites with aluminium matrix reinforced by $\mathrm{SiC}$ (Nissan) or $\mathrm{Al}_{2} \mathrm{O}_{3}$ (Dupondt, Chrysler) are used [8]. By application of aluminium connection rod, reduction of fuel consumption and improvement of engine power are done with simultaneous increase of its total production cost [11].

Further researches of MMC are focused on production of materials that can be used for pistons connecting rods. The prototype of connecting rod made of aluminium MMC is presented in Fig. 6. The researches in this area are still in process.

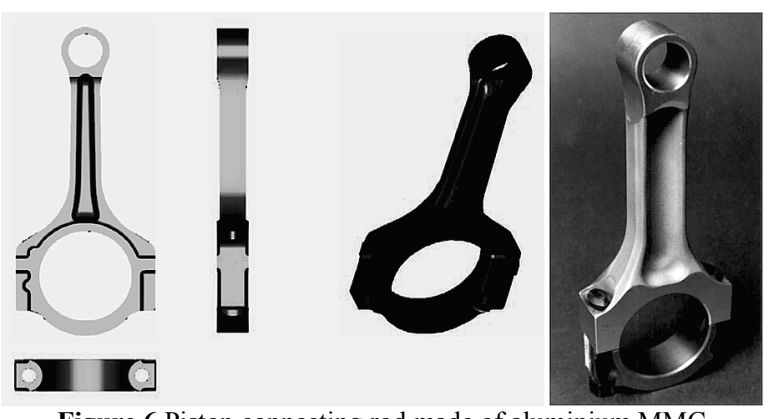

Figure 6 Piston connecting rod made of aluminium MMC

\subsection{Brake systems}

Due to beneficial characteristics, high resistance to wear and high thermal conductivity, aluminium MMC is used for production of break discs and drums at cars. On the basis of the weight reductions, inertial forces are also reduced, so as summary weight of vehicles and fuel consumptions.

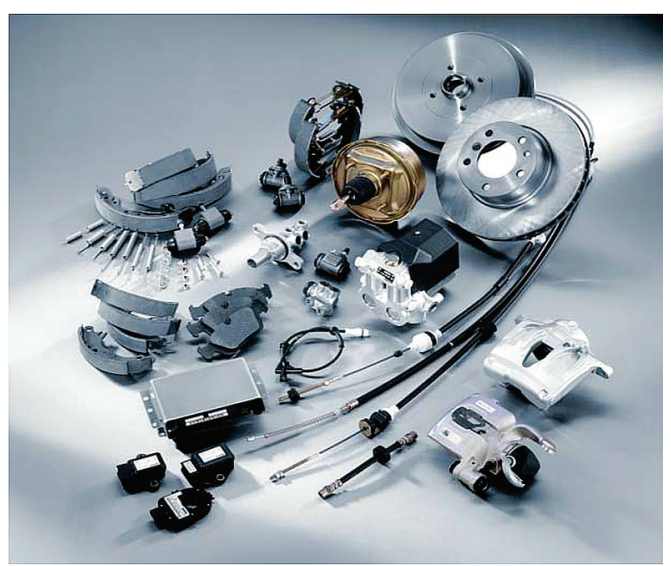

Figure 7 Brake systems made of aluminium MMC

$\mathrm{Al}-\mathrm{Mg}$ and $\mathrm{Al}-\mathrm{Si}$ alloys reinforced by ceramic 
materials such as $\mathrm{SiC}$ and $\mathrm{Al}_{2} \mathrm{O}_{3}$ are used for production of brake discs and drums $[20 \div 25]$. The technology processes for production of composite materials are different casting methods, while volumetric share of reinforcing materials is up to $20 \%$. Large number of producers in automotive industry use aluminium MMC for production of brake systems. At Lotus Elise (1996 1998) all four sets of brake system are made of MMC. PlymonthPromler rear sets of brake system are made of MMC. Uncontinual reinforced aluminium MMC is used for brake discs of Volkswagen Lupo 3L and Audi A2. Hybrid and electrical vehicles are also equipped by brake systems made of aluminium MMC as Toyota RAV4, Ford Prodigy and General Motors Precept [3, 7, 25]. Brake systems made of aluminium MMC are presented in Fig. 7.

Brake discs made of uncontinual reinforced aluminium $\mathrm{MMC}$ are used at high speed trains in Germany - Inter City Express (ICE). Those brake discs are used at ICE-1 and ICE-2 trains on more than 100 train compositions [7].

Aluminium MMC is also used at brake systems of race cars. As materials for brake systems of race cars, $\mathrm{Al}$ $2124 / \mathrm{SiC} / 25 \mathrm{p}$ is used. Braking pads made of MMC are used at Porsche 911. All those composites have ceramic reinforcements.

\subsection{Cardan shaft}

Aluminium MMC is used for production of Cardan shafts due to high specific stiffness. The major disadvantage of present Cardan shafts is critical rotational speed when those shafts become dynamically unstable. Critical rotational speed (number of rotations) of shaft is function of its length, internal and external diameter and specific stiffness. Applications of MMC at Cardan shafts provide alterations of Cardan shafts design solutions, such as: increase of shaft length with constant diameter or decrease of shaft diameter with constant length. By those beneficial possibilities for alterations of design solutions, constructions weight reductions at remained dimensions are obtained. As material, Al6061 reinforced with ceramic material $\mathrm{Al}_{2} \mathrm{O}_{3}$ is used. Those composites were produced by technological process of stir casting. Those Cardan shafts were used for the first time at Chevrolet S-10 and GMC Sonnomo delivery truck in 1997. Cardan shafts made of aluminium MMC were used at Chevrolet Corvette and also at Ford Crown Victoria [3, 7]. The Cardan shaft of Chevrolet Corvette is presented in Fig. 8.

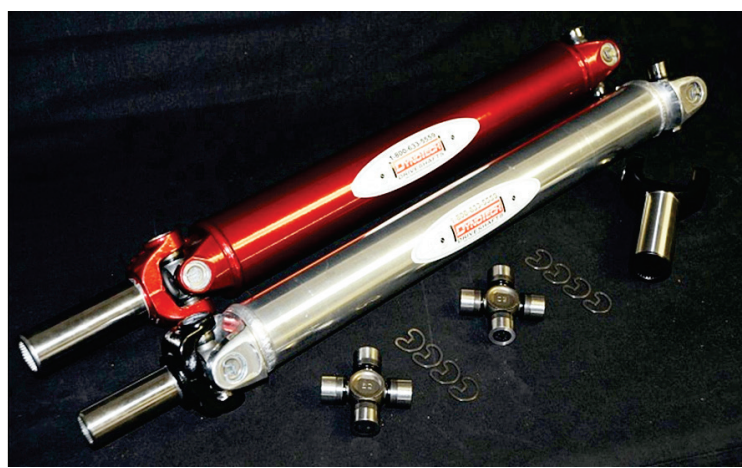

Figure 8 The Cardan shaft of Chevrolet Corvette

\section{Other applications}

MMC with aluminium matrices have very wide area of application. Due to specific characteristics and properties, those materials are used for production of brake calliper assembles, gears, valves, belt pulleys, turbines, turbo-compressors, housings of pumps and supporting parts.

The basic advantages of $\mathrm{MMC}$ as materials for machine parts are higher resistance to wear, low value of thermal expansion coefficients and good thermal properties. The prices of MMC are still high, but with decreasing trend due to quantity of produced parts made of those materials.

\section{Conclusion}

It is obvious that present development of industry is coupled with necessity for application of lightweight materials with beneficial mechanical and tribological characteristics that can fulfil technical and technological requirements. One of the best suited material with characteristics that can provide most of the modern demands is aluminium and its alloys. But, aluminium, as well as some of its alloys, has proper tribological and mechanical properties only as constituent of composites. The common reinforcing materials of metal matrices composite materials are silicon carbide $(\mathrm{SiC})$ and $\mathrm{Al}_{2} \mathrm{O}_{3}$.

Applications of aluminium and composite materials with aluminium base provide design and produce high performance vehicles with safety improvements and improvements of energy efficiency and ecology aspects that are resistant to corrosion and with reduced masses. Composites with aluminium base are usually used for making of engine pistons, cylinders barrel, connection rods, elements of vehicles braking systems, Cardan shafts and so on. By the application of aluminium at vehicle body, indirectly an increase of engine lifetime is done, the same as increase of lifetime of gear box, breaking system, wheels and other vehicle systems.

By application of aluminium composites instead of steels for making of car elements, reduction of their masses is done, as well as reduction of total car mass of 2 $\div 2,5 \mathrm{~kg}$ for every kilogram of used aluminium. From the other side, increase of fuel prices at global world market also caused increase of application of aluminium and its composites instead of steels. Reduction of vehicle mass resulted in reduction of fuel consumption by 5 to $7 \%$.

\section{Acknowledgements}

This paper presents the research results obtained within the framework of the projects TR-35021 and TR35033 financially supported by the Ministry of Education, Science and Technological Development of the Republic of Serbia.

\section{$5 \quad$ References}

[1] Vencl, A.; Rac, A.; Bobić, I. Tribological behaviour of Albased MMCs and their application in automotive industry. // Tribology in Industry. 26, 3-4(2004), pp. 31-38. 
[2] Vencl, A.; Rac, A. New wear resistant Al based materials and their application in automotive industry. // MVM International Journal for Vehicle Mechanics, Engines and Transportation System. 30, Special Edition, (2004), pp. 115-139.

[3] Chawla, N.; Chawla, K. K. Metal-Matrix Composites in Ground Transportation.// Journal of Metals, JOM. 58, 11(2006), pp. 67-70.

[4] Stojanovic, B.; Babic, M.; Mitrovic, S.;Vencl,A.; Miloradovic, N.; Pantic M. Tribological characteristics of aluminium hybrid composites reinforced with silicon carbide and graphite. A review. // Journal of the Balkan Tribological Association. 19, 1(2013), pp.83-96.

[5] Business Communications Company, RGB-108N Metal Matrix Composites in the $21^{\text {st }}$ Century: Markets and Opportunities, 2006. http://www.bccresearch.com/marketresearch/advanced-materials/metal-matrix-compositesmarket-avm012d.html

[6] Metal Matrix Composites (MMC) Market for Ground Transportation, Electronics/Thermal Management, Aerospaceand Other End-users - Global Industry Analysis, Size, Share, Growth, Trends and Forecast, $2013 \div 2019$, http://www.transparencymarketresearch.com/metal-matrixcomposites.html

[7] Hunt, W. H.; Miracle, D. B. Automotive Applications of Metal-Matrix Composites, in: Miracle, D. B.; Donaldson, S. L. (Ed.), ASM Handbook, Volume 21: Composites, ASM International, pp.1029-1032, 2001.

[8] Prasad, S. V.; Asthana, R. Aluminum metal-matrix composites for automotive applications: tribological considerations. // Tribology Letters. 17, 3(2004), pp. 445453.

[9] Pai, B. C.; Rajan, T. P. D.; Pillai, R. M. Aluminium matrix composite castings for automotive applications. // Indian foundry journal. 50, 2004, pp. 30-39.

[10] Allison, J. E.; Cole, G. S. Metal-matrix Composites in the Automotive Industry: opportunities and challenges. // Journal of the Minerals, Metals and Materials Society. 45, 1 (1993), pp. 19-24.

[11] Kevorkijan, V. M. Aluminum Composites for Automotive Applications: A Global Perspective. // Journal of Metals, JOM, 51, 11(1999), pp. 54-58.

[12] Rohatgi, P. K.; Weiss, D.; Gupta, N. Applications of Fly Ash in Synthesizing Low-Cost MMCs for Automotive and Other Applications. // Journal of Metals. JOM, 58, 11(2006), pp. 71-76.

[13] Bechmann, F.; Fallböhmer, P.; Stauber, R.; Rauber, C. et al. Reinforced Light Metals for Automotive Applications. // SAE Technical Paper 2007-01-1228, 2007.

[14] Miracle, D. B. Metal matrix composites - From science to technological significance, Composites Science and Technology. 65, 15-16(2005), pp. 2526-2540.

[15] Macke, A.; Schultz B. F.; Rohatgi P. Metal Matrix Composites Offer the Automotive Industry an Opportunity to Reduce Vehicle Weight, Improve Performance. // Advanced materials \& processes. 3, (2012), pp. 19-23.

[16] Mehedi, M. A. Aluminium matrix composites in automotive application. // International Journal for Industry, Research and Application. 7-8, (2011), pp. 55-58.

[17] Elmarakbi, A. Advanced Composite Materials for Automotive Applications: Structural Integrity and Crashworthiness. John Wiley \& Sons Ltd, 2014.

[18] Miyamoto, N. Automotive Coatings and Applications // ASM Handbook, Volume 5A, Thermal Spray Technology, R.C. Tucker, Jr., editor, 2013.

[19] Donomoto, T.; Funatani, K.; Miura, N.; Miyake, N. Ceramic Fiber Reinforced Piston for High Performance Diesel Engines. // SAE Technical Paper // 830252, 1983.

[20] Daoud, A.; Abou El-khair, M. T. Wear and friction behaviour of sand cast brake rotor made of A359-20 vol. \%
$\mathrm{SiC}$ particle composites sliding against automobile friction material. // Tribology International. 43, 3(2010), pp. 544553.

[21] Goñi, J.; Egizabal, P.; Coleto, J.; Mitxelena, I.; Guridi, J. R. High performance automotive and railway components made from novel competitive aluminium composites. // Materials Science and Technology. 19, 7(2003), pp. 931934

[22] Straffelini, G.; Pellizzari, M.; Molinari, A. Influence of load and temperature on the dry sliding behavior of Al-based metal-matrix-composites against friction material. // Wear, 256, 7-8(2004), pp. 754-763.

[23] Uyyuru, R. K.; Surappa, M. K.; Brusethaug, S. Effect of reinforcement volume fraction and size distribution on the tribological behavior of Al-composite/brake pad tribocouple. // Wear. 260, 11-12(2006), pp. 1248-1255.

[24] Natarajan, N.; Vijayarangan, S.; Rajendran, I.; Wear behavior of A356/25SiCp aluminium matrix composites sliding against automobile friction material. // Wear. 261, 78(2006), pp. 812-822.

[25] Adebisi, A. A.; Maleque, M. A.; Rahman, M. M. Metal matrix composite brake rotor: historical development and product life cycle analysis. // International Journal of Automotive and Mechanical Engineering (IJAME). 4, 1(2011), pp. 471-480.

\section{Authors' addresses}

Blaža Stojanović, PhD, assistant professor Faculty of Engineering, University of Kragujevac Sestre Janjić 6, 34000 Kragujevac, Serbia E-mail: blaza@kg.ac.rs

Lozica Ivanović,PhD, associated professor Faculty of Engineering, University of Kragujevac Sestre Janjić 6, 34000 Kragujevac, Serbia E-mail: lozica@kg.ac.rs 